\title{
PENINGKATAN MOTIVASI BELAJAR DAN KEMAMPUAN BERPIKIR KRITIS SISWA PADA MATERI EKOSISTEM MELALUI PENERAPAN MODEL INKUIRI TERBIMBING
}

\author{
Anisa Zahra He rmayani \\ Sri D wiastuti \\ Marjono
}

\author{
Pendidikan Biologi FKIP UNS \\ E-mail: anzahra89@gmail.com,dwiastuti54@gmail.com, maryonobio@yahoo.com
}

\begin{abstract}
The purposes of this research are to increase students learning motivation and critical thinking skills of class X MIA 5 SMA Batik 1 Surakarta through the implementation mode of guided inquiry. This research is a Classroom Action Research with 2 cycles of action. Each cycle consisting of 4 phases which are planning, acting, observing, and reflecting. Observational data obtained from the observation sheet, questionnaire, and test. Technical analysis of data is descriptive qualitative. Data validation is used triangulation method. The result of this research shows that with the implementation model of guided inquiry learning could increase learning motivation and critical thinking skills in Biological learning. It's based on the result of observation sheet, questionnaire, and test. Average percentage for each aspect of leaming motivation pre-cycle are 45,4\%, first cycle are 65,08\% (increase 19,68\%), and last cycle 75,17\% (increase 10,09\%), while percentage for each aspect of critical thinking skills pre-cycle are $34,17 \%$, first cycle $51,10 \%$ (increase $16,93 \%$ ), and last cycle are 61,73\% (increase 10,63\%). This it can be concluded that the implementation model of Guided Inquiry learning could increase learning motivation and critical thinking skills of students class X MIA 5 SMA Batik 1 Surakarta class year 2014/2015.
\end{abstract}

Kata kunci: Inkuiri terbimb ing, motivasi belajar, keterampilan berpikir kritis

Ilmu pengetahuan merupakan aspek penting dalam kehidupan, hal ini berkaitan dengan tuntutan, tantangan dan persaingan di era globalisasi. Dampaknya menyebabkan berubahnya cara pandang manusia terhadap pendidikan (Hasan, 2003). Era globalisasi selain ditandai dengan perkembangan teknologi dan informasi yang sangat cepat juga tuntutan individu untuk belajar sepanjang hayat. Tuntutan tersebut menginginkan peserta didik yang berkualitas, mampu berpikir kritis, berpikir kreatif, memiliki motivasi belajar yang tinggi dan juga mampu memecahkan masalah dalam kehidupan sehari-hari.

Faktor yang mempengaruhi keberhasilan proses belajar mengajar salah satunya adalah motivasi belajar siswa. Semakin besar motivasi belajar peserta didik, maka semakin berhasil pula peserta didik dalam mencapai hasil belajar yang maksimal. Staton (2009) mengemukakan bahwa seseorang akan berhasil dalam belajar, kalau pada dirinya sendiri ada keinginan untuk belajar.

Berpikir kritis merupakan kemampuan peserta didik untuk berpikir secara netral, memiliki alasan logis, keinginan kuat akan kejelasan dan ketepatan suatu informasi. Berdasarkan pendapat Anderson (2004), apabila berpikir kritis dikembangkan maka peserta didik akan cenderung mencari kebenaran, berpikir terbuka, toleran terhadap ide-ide baru, dapat menganalisis masalah dengan baik dan memiliki rasa ingin tahu yang tinggi. 
Pembelajaran biologi di SMA Batik 1 Surakarta sudah menggunakan Kurikulum 2013 namun ditemui permasalahan diantaranya siswa cenderung bosan karena model pembelajaran yang terlalu monoton dan kurang menarik sehingga kemampuan peserta didik tidak sepenuhnya tereksplorasi dengan baik.Karakteristik mata pelajaran biologi yang cenderung banyak hafalan dan memahami konsep sehingga membuat mata pelajaran ini kurang diminati.

Hal ini berakibat kepada rendahnya motivasi belajar dan kemampuan berpikir kritis peserta didik. Hasil observasi yang sudah dilakukan dan didukung oleh data pengamatan terhadap motivasi belajar dan kemampuan berpikir kritis siswa sebagai berikut: motivasi belajar siswa, adanya hasrat dan keinginan ingin berhasil 40\%, adanya dorongan dan kebutuhan dalam belajar 34,5\%, adanya harapan dan cita-cita masa depan $63 \%$, adanya penghargaan dalam belajar 39\%, adanya kegiatan yang menarik dalam belajar 34,5\%, adanya lingkungan belajar kondusif, sehingga memungkinkan seseorang siswa dapat belajar dengan baik $53,5 \%$, tekun menghadapi tugas $36 \%$, ulet menghadapi tugas $38 \%$, menunjukkan minat terhadap macam-macam masalah $33 \%$, lebih senang bekerja mandiri, cepat bosan pada tugas yang rutin $43 \%$, dapat mempertahankan pendapatnya, tidak mudah melepaskan hal yang diyakini, senang mencari dan memecahkan soal-soal $34,5 \%$, sedangkan data hasil observasi kemampuan berpikir kritis siswa sebagai berikut: interpretation (interpretasi) 7,86\%, Analysis (analisis) 6,07\%, Evaluation (evaluasi) 5,09\%, Inference (kesimpulan) 4,73\%, Explanation (penjelasan) 4,82\%, Self-regulation (pengaturan diri) 5,60\% dengan jumlah skor $34,17 \%$. Berdasarkan hasil observasi disimpulkan bahwa motivasi belajar meliputi aspek adanya hasrat dan keinginan ingin berhasil, adanya dorongan dan kebutuhan dalam belajar, adanya penghargaan dalam belajar, adanya kegiatan yang menarik dalam belajar, tekun menghadapi tugas, ulet menghadapi tugas, menunjukkan minat terhadap macam-macam masalah, cepat bosan pada tugas yang rutin, senang mencari dan memecahkan soal-soal dan jumlah skor kemampuan berpikir kritis siswa rendah.

Alternatif solusi yang dapat digunakan untuk mengatasi permasalahan diatas adalahpenggunaan model pembelajaran yang dapat melibatkan siswa dalam proses pembelajaran dan mampu mengoptimalkan kemampuan berpikir siswa. Inkuiri terbimbing merupakan model pembelajaran yang melibatkan siswa lebih aktif dalam kegiatan pembelajaran untuk menggali potensi yang ada dalam dirinya dengan arahan guru. Model pembelajaran inkuiri terbimbing diharapkan dapat membantu siswa dalam memahami konsep-konsep dasar dan ide-ide yang lebih baik,membantu dalam menggunakan daya ingat siswa sehingga dapat meningkatkan motivasi belajar dan kemampuan berpikir kritis siswa.

\section{METODE}

Penelitian dilaksanakan di kelas X MIA 5 SMA Batik 1 Surakarta tahun pelajaran 2014/2015. SMA Batik 1 Surakarta beralamat di Jalan Slamet Riyadi No 445, Laweyan, Surakarta.Bentuk penelitian ini adalah Penelitian Tindakan Kelas (PTK) atau Classroom Action Research (CAR). Prosedur dan langkah- langkah dalam penelitian tindakan kelas ini mengikuti model yang dikembangkan oleh Kemmis dan Mctaggart (2005) yaitu dalam satu siklus terdiri dari tahap perencanaan, tindakan, observasi, dan refleksi.

Tahap perencanaan pembelajaran meliputi penyusunan instrumen pembelajaran dan instrumen penelitian. Instrumen pmebelajaran terdiri dari silabus, RPP, LKS, dan materi ajar, sedangkan instrumen penelitian terdiri dari lembar observasi, angket,soal tes kemampuan berpikir kritis, lembar observasi keterlaksanaan sintak, dan pedoman wawancara, serta peralatan dokumentasi. 
ANISA Z., SRI, D.\& MARJONO, MOTIVASI BELAJAR DAN KEMAMPUAN ..

Penelitian dilakukan berkolaborasi dengan guru biologi untuk menyelesaikan permasalahan motivasi belajar dan kemampuan berpikir kritis siswa yang dianalisis melalui hasil observasi pra siklus. Solusi dari permasalahan di kelas X MIA 5 berupa penerapan model pembelajaran inkuiri terbimbing dalam pembelajaran biologi pada materi sistem ekosistem.

Penerapan model pembelajaran inkuiri terbimbing dilakukan dalam dua siklus pembelajaran, dengan langkah pembelajaran yang sama. Perbedaan yang terdapat antar siklus adalah bagian refleksi, sebab refleksi didasarkan pada fakta yang diperoleh dari pelaksanaan di lapangan. Kegiatan refleksi di tiap siklus dilakukan untuk mengupayakan perbaikan pembelajaran pada siklus berikutnya.

Data penelitian motivasi belajar dan kemampuan berpikir kritis siswa diperoleh melalui observasi, angket, dan tes tertulis. Observasi dilakukan selama pelaksanaan tindakan penerapan model pembelajaran inkuiri terbimbing. Tes tertulis dan angket dilaksanakan di setiap akhir siklus pembelajaran.

\section{HASIL}

Skor capaian aspek motivasi belajar siswa berdasarkan hasil observasi dan angket pada siklus I dan siklus II dapat dilihat pada Tabel berikut.

Tabel 1. Rata-rata Capaian Skor Tiap Aspek Motivasi Belajar

\begin{tabular}{clcc}
\hline \multirow{2}{*}{ No } & \multicolumn{1}{c}{ Indikator } & \multicolumn{2}{c}{ Capaian Skor (\%) } \\
\cline { 3 - 4 } & & Siklus I & Siklus II \\
\hline 1 & Menunjukkan minat terhadap macam-macam masalah & 65,35 & 76,22 \\
2 & Tekun menghadapi tugas dan ulet menghadapi kesulitan & 65,59 & 77,90 \\
3 & Senang mencari dan memecahkan masalah soal-soal & 57,28 & 67,90 \\
4 & Adanya hasrat dan keinginan berhasil & 60,13 & 72,32 \\
5 & Adanya dorongan dan kebutuhan dalam belajar & 63,00 & 69,67 \\
6 & Cepat bosan pada tugas yang rutin & 64,79 & 76,12 \\
7 & Adanya penghargaan dalam belajar & 60,00 & 74,07 \\
8 & Adanya kegiatan yang menarik dalam belajar & 84,53 & 87,14 \\
\hline & Jumlah & $\mathbf{5 2 0 , 6 6}$ & $\mathbf{6 0 1 , 3 2}$ \\
& Rata-rata & $\mathbf{6 5 , 0 8}$ & $\mathbf{7 5 , 1 7}$ \\
\hline
\end{tabular}

Tabel 1 menunjukkan capaian skor tiap aspek maupun skor rata-rata keseluruhan aspek motivasi belajar dari tahap siklus I dan siklus II. Skor capaian tiap aspek di siklus II berkisar antara $69,67 \%$ sampai $87,14 \%$ dengan skor rata-rata total keseluruhan aspek sebesar $75,17 \%$. Skor tersebut menunjukkan peningkatan jika dibandingkan dengan siklus I, baik untuk setiap aspek maupun rata-rata skor capaian aspek motivasi belajar. Hasil pengukuran motivasi belajar siswa siklus II menunjukkan bahwa sebagian besar aspek sudah mencapai target akhir sebesar $\geq 70 \%$, namun terdapat dua aspek yang belum mencapai target akhir yaitu senang mencari dan memecahkan masalah soal-soal dengan capaian skor sebesar $67,90 \%$ di siklus II dan aspek adanya dorongan dan kebutuhan dalam belajar dengan capaian skor sebesar $69,67 \%$ di siklus II. Berdasarkan Tabel 1 dapat dilihat tingkat kenaikan skor tiap aspek motivasi belajar yang disajikan dalam bentuk diagram pada Gambar 1. Peningkatan terjadi mulai dari siklus I dan siklus II baik dari tiap aspek maupun rata-rata keseluruhan aspek. 
ANISA Z., SRI, D.\& MARJONO, MOTIVASI BELAJAR DAN KEMAMPUAN ..

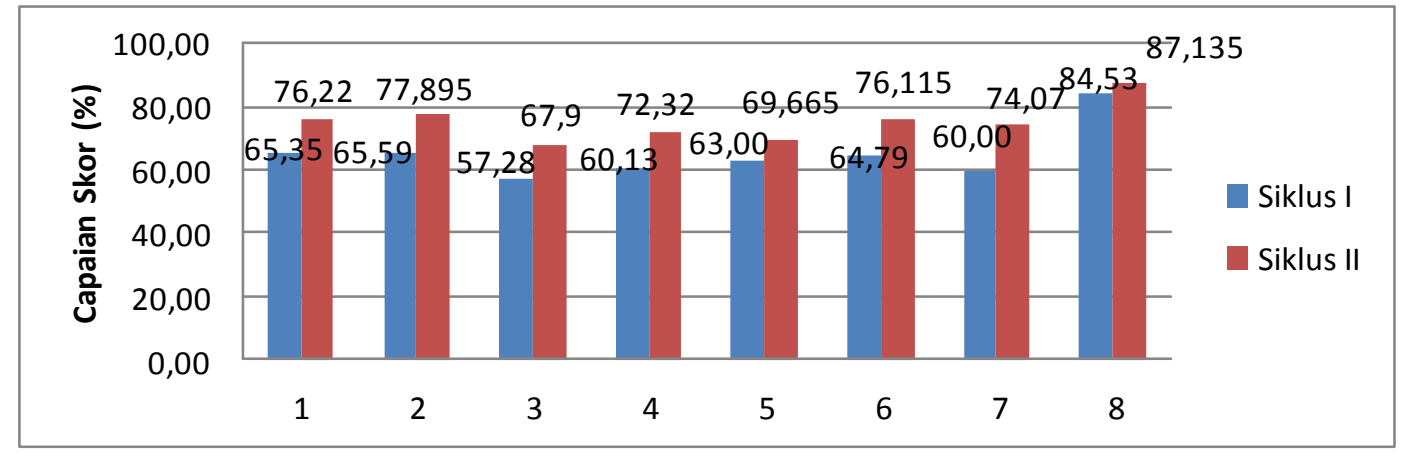

Keterangan Indikator Motivasi Belajar:

1. Menunjukkan minat siswa terhadap macam-macam masalah

2. Tekun menghadapi tugas dan Ulet menghadapi kesulitan

3. Senang mencari dan memecahkan masalah soal-soal

4. Adanya hasrat dan keinginan berhasil

5. Adanya dorongan dan kebutuhan dalam belajar

6. Cepat bosan pada tugas rutin

7. Adanya penghargaan dalam belajar

8. Adanya kegiatan yang menarik dalam belajar

Gambar 1. Peningkatan Capaian Skor tiap Aspek Motivasi Belajar

Berdasarkan data pada Gambar 1 menunjukkan hasil perhitungan persentase motivasi belajar siswa siklus I dan siklus II. Berdasarkan diagram diatas, motivasi belajar siswa mengalami peningkatan pada setiap siklusnya. Hasil perhitungan capaian hasil motivasi belajar siswa pada siklus I berkisar antara $57,28 \%$ sampai $84,53 \%$ dan pada siklus II berkisar antara $67,90 \%$ sampai $87,14 \%$.
Hasil tersebut menunjukkan adanya peningkatan persentase nilai setiap indikator dari setiap siklus. Nilai rata-rata indikator menunjukkan adanya peningkatan persentase dari siklus I sebesar $65,08 \%$ dan siklus II sebesar 75,17\% (meningkat 10,09\%).

Skor capaian aspek kemampuan berpikir kritis siswa berdasarkan hasil tes pada siklus I dan siklus II dapat dilihat pada Tabel berikut

Tabe1 2. Rata-rata Capaian Skor Tiap Aspek Kemampuan Berpikir Kritis

\begin{tabular}{clcc}
\hline \multirow{2}{*}{ No } & & \multicolumn{2}{c}{ Capaian Skor (\%) } \\
\cline { 3 - 4 } & & Siklus I & Siklus II \\
\hline 1 & Interpretation & 10,63 & 12,50 \\
2 & Analysis & 9,38 & 10,54 \\
3 & Evaluation & 8,63 & 9,38 \\
4 & Inference & 7,31 & 9,82 \\
5 & Explanation & 8,34 & 9,02 \\
6 & Self-regulation & 9,38 & 10,48 \\
\hline & Jumlah & $\mathbf{5 1 , 1 0}$ & $\mathbf{6 1 , 7 3}$ \\
& Rata-rata & $\mathbf{8 , 9 4}$ & $\mathbf{1 0 , 2 9}$ \\
\hline
\end{tabular}

Berdasarkan Tabel 2 dapat dilihat hasil capaian indikator kemampuan berpikir kritis siswa pada siklus II berkisar antara 9,02\% sampai $12,5 \%$ dengan skor capaian rata-rata kelas sebesar 10,29\%. Skor tersebut menunjukkan peningkatan jika dibandingkan dengan siklus I, baik untuk setiap aspek 
maupun rata-rata skor capaian aspek kemampuan berpikir kritis. Berdasarkan Tabel 2 dapat dilihat tingkat kenaikan skor tiap aspek kemampuan berpikir kritis yang disajikan dalam bentuk diagram pada Gambar 2 .
Peningkatan terjadi mulai dari siklus I dan siklus II baik dari tiap aspek maupun rata-rata keseluruhan aspek.

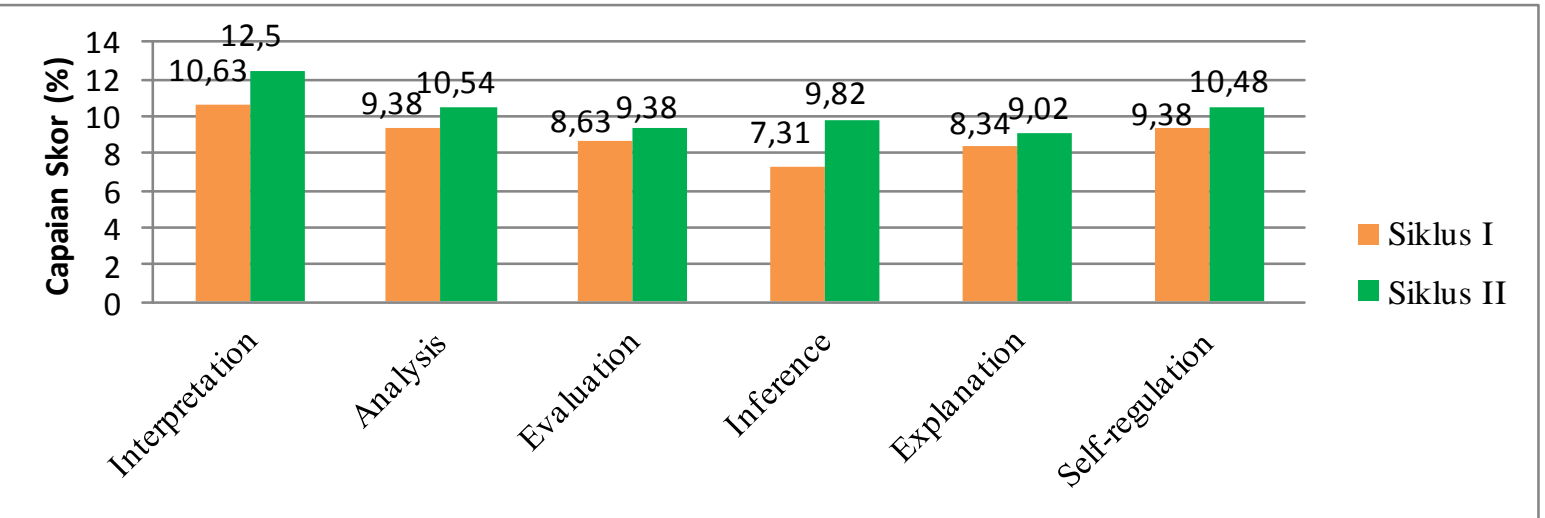

Gambar 2. Peningkatan Capaian Skor tiap Aspek Kemampuan Berpikir Kritis

Berdasarkan data hasil pengamatan didapatkan bahwa hasil jumlah capaian indikator kemampuan berpikir kritis siswa kelas X MIA 5 meningkat sesuai target pada siklus II yaitu sebesar $61,73 \%$ (meningkat $27,56 \%$ ) berdasarkan tes kemampuan berpikir kritis, sedangkan rata-rata capaian indikator motivasi belajar berdasarkan angket meningkat pada siklus II yaitu sebesar $80,07 \%$ (meningkat $34,67 \%$ ) berdasarkan angket. Hal tersebut meningkat dibandingkan dengan hasil capaian pada siklus I. Jumlah capaian indikator kemampuan berpikir kritis pada siklus I sebesar 51,10\% (meningkat 16,93\%), sedangkan rata-rata capaian indikator motivasi belajar meningkat pada siklus I yaitu sebesar 76,23\% (meningkat 30,83\%) berdasarkan angket. Indikator kemampuan berpkir kritis yang diukur adalah aspek interpretation, analysis, evaluation, inference, explanation, dan self-regulation. Indikator motivasi belajar siswa yang diukur adalah aspek menunjukkan minat terhadap macam-macam masalah, tekun menghadapai tugas dan ulet menghadapi kesulitan, senang mencari dan memecahkan soal-soal, adanya hasrat dan keinginan berhasil, adanya dorongan dan kebutuhan dalam belajar, cepat bosan pada tugas rutin, adanya penghargaan dalam belajar, dan adanya kegiatan yang menarik dalam belajar. Data hasil pengukuran berupa skor capaian hasil observasi, tes tertulis dan angket.

Semua indikator kemampuan berpikir kritis dan motivasi belajar siswa dapat ditingkatkan menggunakan model pembelajaran inkuri terbimbing. Tahap-tahap yang terdapat dalam model pembelajaran inkuiri terbimbing meliputi pengenalan area investigasi kepada siswa, siswa menemukan dan mencari permasalahan, siswa mengidentifikasi masalah yang akan diteliti dalam percobaan, dan menentukan langkahlangkah untuk menyelesaikan masalah (Joyce et al., 2000).

\section{PEMBAHASAN}

Berdasarkan penelitian yang telah dilakukan diketahui bahwa model pembelajaran inkuiri terbimbing dapat meningkatkan motivasi belajar dan kemampuan berpikir kritis siswa.hasil penelitian tersebut sesuai dengan hasil penelitian Halimah (2012) bahwa model inkuiri berbasis lesson study melatih siswa menemukan konsep atau jawaban suatu masalah yang menjadikan siswa lebih antusias 
dan mendorong siswa untuk mencari jawaban melalui pengamatan langsung sehingga dapat meningkatkan motivasi siswa untuk belajar. Hasil penelitian Sochibin dkk (2009) mengungkapkan bahwa model pembelajaran inkuiri dapat meningkatkan pemahaman konsep siswa dan menumbuhkembangkan ketrampilan berpikir kritis.

Peningkatan capaian motivasi belajar dan kemampuan berpikir kritis dapat dilihat dari capaian skor setiap siklus pembelajaran mulai dari pra siklus hingga siklus II. Hasil analisis data 8 aspek motivasi belajar dan 6 aspek kemampuan berpikir kritis menunjukan bahwa upaya penerapan model pembelajaran inkuiri mampu meningkatkan motivasi belajar dan kemampuan berpikir kritis siswa hingga akhir siklus II dengan target capaian sebesar $\geq 70 \%$ untuk rata-rata keseluruhan aspek motivasi belajar dan $\geq 60 \%$ untuk jumlah keseluruhan aspek kemampuan berpikir kritis.

Faktor lain yang mempengaruhi peningkatan tiap siklus adalah kualitas pembelajaran yang semakin baik. Proses pembelajaran pada tahap siklus II lebih baik dibandingkan siklus I, sedangkan pembelajaran siklus I lebih baik dibandingkan pra-siklus. Peningkatan kualitas dan keterlaksanaan proses pembelajaran mengakibatkan ketercapaian skor tiap aspek menjadi lebih tinggi. Kualitas pembelajaran dikelola oleh guru. Guru melakukan perbaikan pembelajaran pada tiap siklus melalui tahap refleksi dan perencanaan kembali sebagai upaya perbaikan di siklus berikutnya. Semakin baik kualitas pembelajaran yang dikelola oleh guru di kelas, semakin besar peningkatan kualitas siswa.

Hasil penelitian berupa peningkatan motivasi belajar dan kempuan berpikir kritis siswa didukung melalui wawancra siswa dan guru.Hasil wawancara dengan beberapa perwakilan siswa diperoleh respon terhadap penerapan model pembelajaran inkuiri terbimbing.Siswa sampel yang berjumlah 6 orang menyatakan bahwa pembelajaran yang diterapkan pada materi ekosistem memberikan pengalaman lebih bagi siswa.siswa lebih memahami materi yang disampaikan dan keterlibatan siswa dalam pembelajaran lebih optimal. Pendapat siswa didukung dengan penyataan yang disampaikan oleh guru melalui wawancara dengan guru.

Hasil wawanara dengan guru pada tiap akhir siklus, diperoleh informasi bahwa guru lebih merasa antusias menyampaikan pembelajaran melalui penerapan model inkuiri terbimbing. Keterlibatan siswa dalam setiap kegiatan memberikan dampak positif khususnya terhadap partisipasi siswa saat pembelajaran sehingga materi yang disampaikan guru bisa dipahami dengan baik oleh siswa.guru memberi kesimpulan bahwa penerapan model pembelajaran inkuiri terbimbing dapat meningkatkan motivasi belajar dan kemampuan berpikir kritis siswa.

\section{KESIMPULAN}

Berdasarkan hasil penelitian dapat disimpulkan bahwa ada peningkatan motivasi belajar sebesar 29,77\% dan kemampuan berpikir kritis siswa sebesar 27,56\% melalui penerapan model Inkuiri Terbimbing di kelas X MIA 5 SMA Batik 1 Surakarta tahun pelajaran 2014/2015.

\section{DAFTAR RUJUKAN}

Anderson, J.A. 2004. Critical Thinking Across the Disciplines. Makalah Faculty Development Seminar in New York City College of Technology, New York

Halimah, U. 2012. Penerapan Strategi Pembelajaran Inkuiri Berbasis Lesson Studi Untuk Meningkatakan Motivasi Belajar Dan Hasil Belajar Biologi Siswa Kelas X SMAN 1 Kepanjen Malang. Thesis. Program Studi Pendidikan Biologi Universitas Negeri Malang.

Hasan, A.M. 2003. Pengembangan Profesionalisme Guru di Abad Pengetahuan. [Online] http://re- 
ANISA Z., SRI, D.\& MARJONO, MOTIVASI BELAJAR DAN KEMAMPUAN ..

searchengines.com/amhasan. html.

Diakses 14 Januari 2015

Joyce. B. Weil \& B. Shower. 2000. Models of Teaching Fourth Edition Massa Chusettes: Allymand and Bacon Publishing Company

Kemmis, S \& R. Mctaggart. 2005. Participatory Action Research: Handbook of Qualitative Research.

Sochibin, A., P. Dwijananti, P. Marwoto. 2009. Penerapan Model Pembelajaran Inkuiri Terpimpin untuk Peningkatan Pemahaman dan Keterampilan Berpikir Kritis Siswa SD. Jurnal Pendidikan Indonesia

Staton, T. F. 2009. Cara Mengajar Dengan Hasil Yang Baik. Bandung. CV Dipone goro 